\title{
ANALYSIS OF DIFFERENT PERCEPTIONS ON REFUND, RESCHEDULE, AND ONLINE CHECK-IN SERVICES OF EFRE TOUR \& TRAVEL AND TRAVELOKA
}

\author{
Siswanto Yoseph Erick Wirawan*, Kodrat David Sukardi \\ Master Program in Management, Faculty of Management and Business, \\ University of Cipura Surabaya, Indonesia \\ *E-mail: erick.wirawan05@gmail.com \\ ORCID: 0000-0003-2463-3032
}

\begin{abstract}
Recently, the condition of tour and travel industry is quiet promising. The companies currently compete not only about promotion, pricing, and services but also about providing after-sales services that are required by the customers. There were the same after-sales services owned by ERFE Tour \& Travel and Traveloka, namely refund, reschedule, and online check-in services. The problem of this research was that both companies had the same after-sales service and the regulation of the services was also determined by the airline company, but there was a possibility that customer's perception of both companies might differ in response to this. Therefore, this research aimed to examine whether there were different perceptions in refund, reschedule, and online check-in services between ERFE Tour \& Travel and Traveloka. The data analysis of this research applied Manova method. The findings of this research showed that there was different perception on refund service between ERFE Tour \& Travel and Traveloka. It indicated that there was no different perception on reschedule and online check-in services between ERFE Tour \& Travel and Traveloka.
\end{abstract}

\section{KEY WORDS}

Service, after-sales service, perception, refund, reschedule, online check-in.

Currently, Indonesia's tourism sector is one of the important economic sectors in Indonesia. According to the available data on the website of Indonesia Investment, in 2016, Indonesia's tourism sector contributed about $11 \%$ of total Gross Domestic Product. According to the same source, by 2017 , the contribution of the tourism sector will grow to $13 \%$ and will continue to grow from year to year.

By 2015, based on the data from the Central Bureau of Statistics, the number of foreign tourists coming to Indonesia was 9.7 million or increased about 300,000 from the previous year. Since 2007, the number of foreign tourists coming to Indonesia has increased steadily. The natural resources and diverse cultures are the important component of tourism in Indonesia. Based on data from the Central Bureau of Statistics, some of the most visited provinces are Bali, DKI Jakarta, Special Region of Yogyakarta, East Java, West Java, North Sumatra, Lampung, South Sulawesi, South Sumatra, Banten, and West Sumatra.

By 2019, the Indonesian government wanted to increase the revenue two-fold from the tourism sector. The increase is derived from the two-fold increase of foreign tourists or approximately 20 million tourists. Therefore, the government is currently supporting the progress of tourism in Indonesia. The support is realized in the improvement of Indonesia's infrastructure (including technology and communications infrastructure), access (road), cleanliness of tourism objects, and also the enhancement of online promotion that can be seen by the foreign tourists to get to know Indonesia better. In addition, the government also revised the policy of free access visa which has set in 2015 to citizens from 45 countries.

With the improvements in some parts of Indonesia's tourism, not only foreign tourists, local tourists will also be interested to do travelling. The increasing number of tourists will create various business opportunities. The increasing number of tourists will also increase the demand for lodging so that it can attract local and foreign investors to invest in additional lodging (Pleanggra and Yusuf, 2012). In addition, the need for places or tourist rides will also 
increase that will cause the foreign investors to invest in Indonesia. The companies engaged in the field of tour and travel also take advantages to this matter. According to Saleh (2013), in his article available on the website industry.bisnis.com, in 2013 there were about 4000 companies engaged in this field and the numbers tended to rise and fall from time to time.

Industrial condition in the field of tour and travel is currently quite promising. This is because the current number of tourists is increasing, both foreign and local tourists. Based on data from the Central Bureau of Statistics, the number of tourists coming to Indonesia has increased cumulatively from January to February 2017 of $16.91 \%$.

Currently, companies engaged in this field compete for get customers. The companies compete in terms of price, promotion, and services they provide. This creates a newly established company that cannot do the same strategy as the previous companies. Nowadays, the companies more focus on the provided services because all the major companies do the pricing strategy. The provided services including the search process, payment, and even the companies recently provide after-sales service.

ERFE Tour \& Travel is a newly established company so it still needs to set a strategy to get more customers in the future. ERFE Tour \& Travel is a provider of traveling services such as airfare, hotel (domestic and overseas), tour (domestic and overseas), and handling the necessary letters/ documents for travelling. By 2017, the contribution of each service provided by the company was $40 \%$ for airfare, $40 \%$ for hotel, $15 \%$ for tour, and $5 \%$ for handling the letters/ documents. Currently the company has implemented an online system (not necessarily face-to-face/ meet) to serve their customers. The problem faced the company recently is that the company needs to focus on how the application of after-sales service is needed by the customers. The followings are some after-sales services provided by ERFE Tour \& Travel as well as the competing companies that are engaged in the same field of business.

Table 1 - Companies' After-Sales Services

\begin{tabular}{|c|c|c|}
\hline $\begin{array}{l}\text { Type of } \\
\text { Service }\end{array}$ & ERFE Tour \& Travel & Traveloka \\
\hline Refund & $\begin{array}{l}\text { In accordance with the provisions of the airline } \\
\text { and government }\end{array}$ & $\begin{array}{l}\text { In accordance with the provisions of the } \\
\text { airline and government }\end{array}$ \\
\hline Reschedule & $\begin{array}{l}\text { In accordance with the provisions of the airline } \\
\text { and government }\end{array}$ & $\begin{array}{l}\text { In accordance with the provisions of the } \\
\text { airline and government }\end{array}$ \\
\hline $\begin{array}{l}\text { Online Check- } \\
\text { In }\end{array}$ & $\begin{array}{l}\text { In accordance with the provisions of the airline } \\
\text { (mostly } 24 \text { hours before departure) and can be } \\
\text { represented by the travel party }\end{array}$ & $\begin{array}{l}\text { In accordance with the provisions of the } \\
\text { airline (mostly } 24 \text { hours before departure) and } \\
\text { is made the customers themselves }\end{array}$ \\
\hline Point & No & Traveloka Point \\
\hline Price Alert & No & Price Alert \\
\hline $\begin{array}{l}\text { Travelers } \\
\text { Picker }\end{array}$ & No & $\begin{array}{l}\text { Keeping the details of passengers who have } \\
\text { ever made booking }\end{array}$ \\
\hline Feedback & $\begin{array}{l}\text { Positives: } \\
\text { - } \quad \text { Fast service } \\
\text { - } \quad \text { Purchase is served } 24 \text { hours non- } \\
\text { - } \quad \text { Stop } \\
\text { Negatives: } \\
\text { - Lack of promo } \\
\text { - Lack number of hotels } \\
\text { - Long search process for tickets/ } \\
\quad \text { hotels }\end{array}$ & 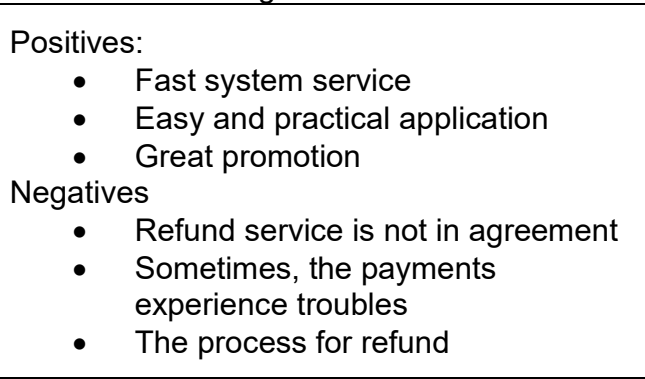 \\
\hline $\begin{array}{l}\text { Newsletter and } \\
\text { Promo Info }\end{array}$ & No & Yes \\
\hline $\begin{array}{l}\text { Push } \\
\text { Notification }\end{array}$ & No & Yes \\
\hline
\end{tabular}

Source: the processed data (2018).

Based on Table 1, there are the same after-sales services provided by ERFE Tour \& Travel and Traveloka. The same after-sales services are refund service, reschedule service, 
and online check-in service. From the three after-sales services, the existing provisions are determined not from the company of service provider but by the respective airlines. Therefore, the three after-sales services provided to customers from each company are considered as the same because the existing provisions are made by the airline company rather than the company of service provider.

This research will focus more on the different perceptions on after-sales services consisting of refund service, reschedule service, and online check-in service. This research is conducted because the after-sales services from the two service provider companies have the same provision but it may have different customer's perceptions. Kotler \& Keller (2009) mentioned that in marketing, perception is more important than reality because perception affects the actual behavior of the customers. By conducting this research, it is expected to improve knowledge for business owners of ERFE Tour \& Travel about customer perceptions on after-sales services in the forms of refund, reschedule, and online check-in.

Research Problems. Based on the above background of the research, the formulation of the research problems are the following:

- Is there any different perception on refund service between ERFE Tour \& Travel and Traveloka?

- Is there any different perception on reschedule service between ERFE Tour \& Travel and Traveloka?

- Is there any different perception on online check-in service between ERFE Tour \& Travel and Traveloka?

Research Objectives. Based on the formulation of the above problems, the research objectives are the following:

- To analyze different perception on refund service between ERFE Tour \& Travel and Traveloka;

- To analyze different perception on reschedule service between ERFE Tour \& Travel and Traveloka;

- To analyze different perception on online check-in service between ERFE Tour \& Travel and Traveloka.

\section{METHODS OF RESEARCH}

This study was a quantitative research. The type of this research was comparative research because the problem formulation in this research was comparative problem formulation which analyzed different perceptions on refund service, reschedule service and online check-in service between ERFE Tour \& Travel and Traveloka. According Sugiyono (2014) the formulation of comparative problem is the formulation of a research problem that compares the existence of one or more variables in two or more different samples, or at different times.

Population and Samples. The population of ERFE Tour \& Travel was around 1,500 people. On the website beritasatu.com, the number of Traveloka app downloaders ranged around 15 million users. The sampling technique used in this research was simple random sampling. According to Sugiyono (2014), simple random sampling is the sampling technique that is conducted randomly without any regard to strata of the population. The selection of the sample with the application of that method is carried out when the population members are considered as homogeneous. In this research, the populations that were going to be used were those who have used the services in the field of tour and travel respectively. In addition, it also included the customers who had ever used refund, reschedule, and online check-in services. According to Santoso (2017), the number of samples in a research applying Manova method should amount to 20 respondents per group. In this research, there were 2 groups that would be tested (ERFE Tour \& Travel and Traveloka) so that the number of the samples was 40 respondents. The respondents that were going to be used in this research were 20 customers from ERFE Tour \& Travel and 20 customers from Traveloka. After conducting several outlier tests, the number of the existing data was 20 customers from ERFE Tour \& Travel and 11 customers from Traveloka. 
Data Analysis. In this research, the analysis method for data obtained to draw the conclusions was Manova Analysis (Huberty and Olejnik, 2006). In this research, Manova was used to test the hypothesis of customer's different perception on refund service, reschedule service and online check-in service in ERFE Tour \& Travel and Traveloka. According to Santoso (2017), the basic processes of Manova are:

- Testing the assumptions of Manova data;

- Testing the differences between the groups (The core of Manova);

- Interpreting the output as well as the result of validation process.

\section{RESULTS OF STUDY}

Outlier test is used to distinguish the data that are significantly different from the other existing data (Aggarwal, 2015). The data are not considered to be outlier if the standardized value $(Z)$ of the data is between -2.5 to +2.5 (Santoso, 2017). If there are any have a value exceeding the limit, then it can be considered that the data are outlier. Based on the outlier test results in this research, some of the results stated that some data were classified as outlier. Several outlier tests had been conducted for the data of this research. The following is the final results of the outlier test:

Table 2 - Outlier Test

\begin{tabular}{|c|c|c|c|}
\hline Company & Z-refund & Z-reschedule & Z-online check-in \\
\hline 1 & -1.77165 & -0.97999 & -1.52409 \\
\hline 1 & -1.01015 & -1.66599 & -0.89121 \\
\hline 1 & -1.01015 & -0.97999 & -0.89121 \\
\hline 1 & -0.24865 & -0.29400 & -0.25832 \\
\hline 1 & -0.24865 & -0.29400 & -0.25832 \\
\hline 1 & -0.24865 & -0.29400 & -0.25832 \\
\hline 1 & -0.24865 & -0.29400 & -0.25832 \\
\hline 1 & -0.24865 & -0.29400 & -0.25832 \\
\hline 1 & -0.24865 & -0.29400 & -0.25832 \\
\hline 1 & 0.51285 & -0.97999 & -0.89121 \\
\hline 1 & 0.51285 & 0.39200 & -0.25832 \\
\hline 1 & 0.51285 & -0.29400 & 0.37457 \\
\hline 1 & 0.51285 & 0.39200 & 0.37457 \\
\hline 1 & 1.27435 & 1.76399 & 1.64034 \\
\hline 1 & 2.03585 & 1.07799 & 1.64034 \\
\hline 1 & 2.03585 & 1.76399 & 1.64034 \\
\hline 1 & 2.03585 & 1.76399 & 1.64034 \\
\hline 1 & 2.03585 & 1.76399 & 1.64034 \\
\hline 1 & 2.03585 & 1.76399 & 1.64034 \\
\hline 1 & 2.03585 & 1.76399 & 1.64034 \\
\hline 2 & -1.01015 & -0.97999 & -0.89121 \\
\hline 2 & -1.01015 & -0.97999 & -0.89121 \\
\hline 2 & -1.01015 & -0.97999 & -0.89121 \\
\hline 2 & -1.01015 & -0.97999 & -0.89121 \\
\hline 2 & -1.01015 & 1.76399 & -0.89121 \\
\hline 2 & -0.24865 & -0.97999 & 0.37457 \\
\hline 2 & -0.24865 & 1.76399 & 1.64034 \\
\hline 2 & 0.51285 & -0.97999 & -1.52409 \\
\hline 2 & 0.51285 & 0.39200 & 0.37457 \\
\hline 2 & 0.51285 & 1.07799 & 1.00745 \\
\hline 2 & 0.51285 & 0.39200 & 1.64034 \\
\hline
\end{tabular}

In this research, there were 40 respondents who had answered the questions of the questionnaire. From the 40 respondents, there were some data that had the standardized value $(Z)$ exceeding the upper limit or is below the bottom limit. The data that exceeded the limit were 9 respondents so that current data that did not contain outlier amounted to 31 respondents. In the next test, the data that were going to be used were the data that did not contain outliers. 
The Kaiser Meyer Olkin test is used to determine the adequacy of the data in the research. In this research, after conducting the outlier test there were some discarded data because they were outlier. Therefore, the amount of data that had been through the outlier test would be tested for its data adequacy. The following is the Kaiser Meyer Olkin test:

Table 3 - Kaiser Meyer Olkin Test

\begin{tabular}{|lll|}
\hline KMO and Bartlett's Test & & .738 \\
\hline Kaiser-Meyer-Olkin Measure of Sampling Adequacy & & 64.881 \\
\hline Bartlett's Test of Sphericity & Approx. Chi-Square & 3 \\
\hline & df & Sig. \\
\hline
\end{tabular}

Based on the results of $\mathrm{KMO}$ test, it was found that the value was 0.738 which was more than 0.5 so it could be considered that the data had good criteria (Field, 2009). Therefore, the total data, after conducting the outlier test, was considered to be adequate or has good criteria and they could be used for further testing.

Normality test was performed to see if the data have been normally distributed. The data are considered to be normal if the significance rate of Kolmogorov-Smirnov is more than 0.05 and if they are less, it can be said that the data are not normally distributed. The following is the results of the normality test:

Table 4 - Normality Test

\begin{tabular}{|c|c|c|c|c|c|c|}
\hline \multirow[t]{2}{*}{ Normality Test } & \multicolumn{3}{|c|}{ Kolmogorov-Smirnov ${ }^{a}$} & \multicolumn{3}{|c|}{ Shapiro-Wilk } \\
\hline & Statistic & df & Sig. & Statistic & df & Sig. \\
\hline Refund Average & .177 & 31 & .014 & .894 & 31 & .005 \\
\hline Reschedule Average & .207 & 31 & .002 & .857 & 31 & .001 \\
\hline Online Check-In Average & .200 & 31 & .003 & .859 & 31 & .001 \\
\hline
\end{tabular}

From the obtained results, it was found that the data of this research did not meet the criteria to be normally distributed. This was because the significance value of each variable was less than 0.05 . But in a multivariate research, performing a normality test is very complex. Therefore, it could be assumed that each dependent variable was normally distributed or it was close to normal (Santoso, 2017). In addition, in this research, all the outlier data had been omitted.

Box's $M$ test was used to find out the similarity of variance-covariance matrices for the dependent variables (Mendenhall et al., 2012). The following is the results of Box's M test in this research:

Table 5 - Box's M Test

\begin{tabular}{|l|l|}
\hline Box's Test of Equality of Covariance Matrices & \\
\hline Box's M & 33.533 \\
\hline F & 4.861 \\
\hline df1 & 6 \\
\hline df2 & 2740.573 \\
\hline Sig. & .000 \\
\hline
\end{tabular}

The analysis of the research hypotheses is:

- $\mathrm{H}_{0}$ : The three dependent variables (refund service, reschedule service and online check-in service) have the same variance-covariance matrix, both ERFE Tour \& Travel and Traveloka;

- $\mathrm{H}_{1}$ : The three dependent variables (refund service, reschedule service and online check-in service) have different variance-covariance matrix, both ERFE Tour \& Travel and Traveloka. 
In Box's $M$ test, if the significance value is more than 0.05 then $\mathrm{H}_{0}$ is accepted, but if the significance value is less than 0.05 then $\mathrm{H}_{0}$ is rejected. Based on the results of this test, the significance value was 0.000 in which it was less than 0.05 so it could be said that $\mathrm{H}_{0}$ was rejected. It meant that the variance-covariance matrix of the variables of refund, reschedule and online check-in services was different for either the ERFE Tour \& Travel group or Traveloka group. Since the available data obtained from the test were not equal, the results of Box's M test were ignored (Tabachnick \& Fidell, 2001).

Levene test was used to see the variance-covariance matrix of each dependent variable. The following is the result of Levene test of the research:

Table 6 - Levene Test

\begin{tabular}{|l|l|l|l|l|}
\hline Levene's Test of Equality of Error Variances $^{2}$ & F & Sig. \\
\hline $\mathrm{n} / \mathrm{n}$ & 2.959 & df1 & df2 & S \\
\hline Refund & .037 & 1 & 29 & .096 \\
\hline Reschedule & .081 & 1 & 29 & .850 \\
\hline Online Check-In & 1 & 29 & .779 \\
\hline
\end{tabular}

The description of Table 6 on the Levene test is as the following:

- $\mathrm{H}_{0}=$ the dependent variable (refund service) had the same variance-covariance matrix both in ERFE Tour \& Travel and Traveloka;

- $\mathrm{H}_{1}=$ the dependent variable (refund service) had different variance-covariance matrix both in ERFE Tour \& Travel and Traveloka.

It could be seen that the significance value was .096 so it could be said that the variance-covariance matrix of refund service is individually the same for each group of ERFE Tour \& Travel or Traveloka.

- $\mathrm{H}_{0}=$ the dependent variable (reschedule service) had the same variance-covariance matrix both in ERFE Tour \& Travel and Traveloka;

- $\mathrm{H}_{1}=$ the dependent variable (reschedule service) had different variance-covariance matrix both in ERFE Tour \& Travel and Traveloka.

It could be seen that the significance value was .850 so it could be said that the variance-covariance matrix of reschedule service is individually the same for each group of ERFE Tour \& Travel or Traveloka.

- $\mathrm{H}_{0}=$ the dependent variable (online check-in service) had different variancecovariance matrix both in ERFE Tour \& Travel and Traveloka;

- $\mathrm{H}_{1}=$ the dependent variable (online check-in service) had different variancecovariance matrix both in ERFE Tour \& Travel and Traveloka.

It could be seen that the significance value was .779 so it could be said that the variance-covariance matrix of online check-in service is individually the same for each group of ERFE Tour \& Travel or Traveloka.

Based on the results of Levene test for each dependent variable, it was found that the variance-covariance matrix was the same. Therefore, it could be said that the assumed variance-covariance was met and the analysis process of Manova output could proceed.

Multivariate Test was conducted to determine whether there were significant differences in the dependent variables (refund service, reschedule service and online checkin service) between ERFE Tour \& Travel and Traveloka. This test would obtain the significance value of Wilks' Lambda. If the significance value of Wilks' Lambda was less than 0.05 then it could be said that there was a significant difference in the dependent variables between the two groups, but if the significance value of Wilks' Lambda was more than 0.05 then it could be said that there was no significant difference in the dependent variables between the two groups. The following is the results of Multivariate Test:

- $\mathrm{H}_{0}=$ the dependent variables (refund, reschedule, and online check-in) simultaneously showed no difference both in ERFE Tour \& Travel and Traveloka;

- $\mathrm{H}_{1}=$ the dependent variables (refund, reschedule, and online check-in) simultaneously showed differences both in ERFE Tour \& Travel and Traveloka. 
Table 7 - Multivariate Test

\begin{tabular}{|c|c|c|c|c|c|c|}
\hline \multicolumn{2}{|c|}{$\begin{array}{l}\text { Multivariate Test } \\
\text { Effect }\end{array}$} & \multirow{2}{*}{$\begin{array}{l}\text { Value } \\
.994\end{array}$} & \multirow{2}{*}{$\begin{array}{l}\mathrm{F} \\
1424.462^{b}\end{array}$} & \multirow{2}{*}{$\begin{array}{l}\text { Hypothesis df } \\
3.000\end{array}$} & \multirow{2}{*}{$\frac{\text { Error df }}{27.000}$} & \multirow{2}{*}{$\frac{\text { Sig. }}{.000}$} \\
\hline Intercept & Pillai's Trace & & & & & \\
\hline & Wilks' Lambda & .006 & $1424.462^{b}$ & 3.000 & 27.000 & .000 \\
\hline & Hotelling's Trace & 158.274 & $1424.462^{b}$ & 3.000 & 27.000 & .000 \\
\hline & Roy's Largest Root & 158.274 & $1424.462^{b}$ & 3.000 & 27.000 & .000 \\
\hline \multirow[t]{4}{*}{ Perusahaan } & Pillai's Trace & .178 & $1.948^{\mathrm{b}}$ & 3.000 & 27.000 & .146 \\
\hline & Wilks' Lambda & .822 & $1.948^{b}$ & 3.000 & 27.000 & .146 \\
\hline & Hotelling's Trace & .216 & $1.948^{\mathrm{D}}$ & 3.000 & 27.000 & .146 \\
\hline & Roy's Largest Root & .216 & $1.948^{\mathrm{b}}$ & 3.000 & 27.000 & .146 \\
\hline
\end{tabular}

From Table 7, it was known that the significance value of Wilks' Lambda was 0.146. Therefore, it could be argued that in this research, $\mathrm{H}_{0}$ was accepted so that there was no significant difference on the refund service, reschedule service and online check-in service for both companies.

Test of Between-Subjects Effects was conducted to test whether there were significant differences of each dependent variable (refund service, reschedule service and online checkin service) between ERFE Tour \& Travel and Traveloka. Based on this test, if the result of significance value of each variable was less than 0.05 it could be said that there were significant differences between the two groups, but if the significance value was more than 0.05 then there was no significant difference between the two groups. The following is the results of the Between-Subjects Effects test:

Table 8 - Test of Between-Subjects Effects

\begin{tabular}{|c|c|c|c|c|c|c|}
\hline Source & Dependent Variable & Type III Sum of Squares & $\mathrm{df}$ & Mean Square & $\mathrm{F}$ & Sig. \\
\hline \multirow{3}{*}{ Corrected Model } & Refund Average & $.528^{\mathrm{a}}$ & 1 & .528 & 4.304 & .047 \\
\hline & Reschedule Average & $.105^{\mathrm{b}}$ & 1 & .105 & .600 & .445 \\
\hline & Check-In Online Average & $.175^{\mathrm{C}}$ & 1 & .175 & .920 & .345 \\
\hline \multirow{3}{*}{ Intercept } & Refund Average & 540.528 & 1 & 540.528 & 4407.115 & .000 \\
\hline & Reschedule Average & 550.000 & 1 & 550.000 & 3146.909 & .000 \\
\hline & Check-In Online Average & 548.723 & 1 & 548.723 & 2893.864 & .000 \\
\hline \multirow{3}{*}{ Company } & Refund Average & .528 & 1 & .528 & 4.304 & .047 \\
\hline & Reschedule Average & .105 & 1 & .105 & .600 & .445 \\
\hline & Check-In Online Average & .175 & 1 & .175 & .920 & .345 \\
\hline \multirow{3}{*}{ Error } & Refund Average & 3.557 & 29 & .123 & & \\
\hline & Reschedule Average & 5.068 & 29 & .175 & & \\
\hline & Check-In Online Average & 5.499 & 29 & .190 & & \\
\hline \multirow{3}{*}{ Total } & Refund Average & 605.125 & 31 & & & \\
\hline & Reschedule Average & 610.625 & 31 & & & \\
\hline & Check-In Online Average & 611.125 & 31 & & & \\
\hline \multirow{3}{*}{ Corrected Total } & Refund Average & 4.085 & 30 & & & \\
\hline & Reschedule Average & 5.173 & 30 & & & \\
\hline & Check-In Online Average & 5.673 & 30 & & & \\
\hline \multicolumn{7}{|c|}{$\begin{array}{l}\text { a. } R \text { Squared }=.129 \text { (Adjusted R Squared }=.099) \\
\text { b. } R \text { Squared }=.020 \text { (Adjusted R Squared }=-.014 \text { ) } \\
\text { c. } R \text { Squared }=.031 \text { (Adjusted R Squared }=-.003 \text { ) }\end{array}$} \\
\hline
\end{tabular}

The description of the test results in Table 8 is as follows:

- $\mathrm{H}_{0}=$ refund variable did not show the real difference between ERFE Tour \& Travel and Traveloka.

- $\mathrm{H}_{1}=$ refund variable showed the real difference between ERFE Tour \& Travel and Traveloka.

The test result of the refund variable showed the significance value of 0.047 . The significance value was less than 0.05 so it could be said that $\mathrm{H}_{0}$ was rejected. In this 
research, the refund variable showed the real difference between ERFE Tour \& Travel and Traveloka.

- $\mathrm{H}_{0}=$ reschedule variable did not show the real difference between ERFE Tour \& Travel and Traveloka.

- $\mathrm{H}_{1}=$ reschedule variable showed the real difference between ERFE Tour \& Travel and Traveloka.

The test result of the reschedule variable showed the significance value of 0.445 . The significance value was more than 0.05 so it could be said that $\mathrm{H}_{0}$ was accepted. In this research, the reschedule variable did not show the real difference between ERFE Tour \& Travel and Traveloka.

- $\mathrm{H}_{0}=$ online check-in variable did not show the real difference between ERFE Tour \& Travel and Traveloka.

- $\mathrm{H}_{1}=$ online check-in variable showed the real difference between ERFE Tour \& Travel and Traveloka.

The test result of the online check-in variable showed the significance value of 0.345 . The significance value was more than 0.05 so it could be said that $\mathrm{H}_{0}$ was accepted. In this research, the online check-in variable did not show the real difference between ERFE Tour \& Travel and Traveloka.

\section{DISCUSSION OF RESULTS}

Perception on Refund between ERFE Tour \& Travel and Traveloka. Based on the test results, it was found that there was different perception between ERFE Tour \& Travel customers and Traveloka customers in the refund variable. In this case, the different perception could be affected by the provision of refund information to the customers. Traveloka had already provided information about the refund rules of each airline so that the customers could find out how the rules of the airlines they were going to make refund. So far, ERFE Tour \& Travel had not provided the information as what had been done by Traveloka. All this time, ERFE Tour \& Travel only informed the refund nominal to the customers without providing refund information from each airline. In terms of government regulations, regarding the refund, both ERFE Tour \& Traveloka still did not provide information about it. In addition, the refund system from Traveloka was application-based. By using the application, the customers could refund quickly and easily. Meanwhile, ERFE Tour \& Travel did not use the application and still used online media or phone calling from the customers to the company to inform the company if the customers wanted to do refund. Based on a research conducted by Graham et al. (2010), most cancellations were made by the customers who mainly like to travel. Therefore, the customers would prefer a company that provided services they need in more easily and quickly ways. Based on this discussion, ERFE Tour \& Travel is required to improve its services to make the customers feel satisfied in doing refund.

Perception on Reschedule between ERFE Tour \& Travel and Traveloka. Based on the test results, it was found that there was no different perception on reschedule variable between ERFE Tour \& Travel and Traveloka. It showed that ERFE Tour \& Travel, which had only been established for almost two years, could have the same customer perception as Traveloka that had been established since 2012. Therefore, the customer perception on ERFE Tour \& Travel and Traveloka services had no difference. In this case, perception did not make a difference because the respondent's point of view to the services was the same. However, if it was viewed from the fact of the services performed by each company, there was still a clear difference. The first difference was that Traveloka had provided information about reschedule from each airline so that the customers could read it clearly. Meanwhile, ERFE Tour \& Travel had never had any information that the customers could read as what Traveloka had done. The next was about the speed of the service in which Traveloka was already using the application so if the customers wanted to do reschedule, they could do it quickly and easily. In addition, the apparent difference of the reschedule service was the administration fee given to the customers of each company in which ERFE Tour \& Travel charged IDR 25,000 per booking code while for Traveloka charged IDR 15,000 per 
passenger per route. Based on research conducted by Graham et al. (2010), the research findings indicated that the customers have greater desire to make changes to the schedule when they are approaching the scheduled departure of their tickets because at the approaching scheduled departure, the customers will do the reschedule in a hurry so that the tickets they have at least not become $100 \%$ invalid.

Perception on Online Check-In between ERFE Tour \& Travel and Traveloka. Based on the test results, it was found that there was no different perception because online check-in rules were all governed by each airline. Therefore, the responses of the respondents showed that it had no difference because they assume that all regulations were made by the airline not the company. However in this case, the online check-in service provided by ERFE Tour \& Travel should be better than that what was provided by Traveloka. It was because ERFE Tour \& Travel provide the services so that the customers may have it and they only needed to mention the booking number and name listed on the ticket and seat number they want. After that, the company would check whether it was available. The customers could directly do online check-in and the latest ticket would be sent to them immediately. On the other hand, Traveloka did provide online check-in service but the customer had to do it by themselves. It might be done if the consumer is accustomed to do so but if they were not accustomed to do online check-in by themselves, then they might be confused and it would take a long time. A research article by Murali et al. (2016) mentions that after sales service significantly affects customer satisfaction toward the products or services they use.

Limitations of the Research. In conducting a research, there will be definitely some limitations experienced by the researchers. Below are the limitations in conducting this research, among others:

- Regulation of each service was in accordance with the provisions of the airline so that the respondents could have the same perceptions with other respondents that resulted in the absence of different perception.

- It was difficult to know to what extent the seriousness of the respondents in filling in the questions existing in the distributed questionnaires.

- There was a possibility that some respondents might not use any of the services analyzed in this research. After rechecking the respondents, there were indeed respondents who did not use any of the three services analyzed here.

\section{CONCLUSION}

Based on the findings of the research that had been conducted, several conclusions were obtained. These conclusions would answer all the questions existing in the formulation of the research problems, among others:

There was a different perception on refund service between ERFE Tour \& Travel and Traveloka. It was viewed from the significance value in the Test of Between-Subjects Effects of 0.047 which meant that it was below 0.05 so it could be concluded that there was a difference in refund service on both companies.

There was no different perception on reschedule service between ERFE Tour \& Travel and Traveloka. It was viewed from the significance value in the Test of Between-Subjects Effects of 0.445 which meant that it was above 0.05 so it could be concluded that there was no difference in reschedule service on both companies.

There was no different perception on online check-in service between ERFE Tour \& Travel and Traveloka. It was viewed from the significance value in the Test of BetweenSubjects Effects of 0.345 which meant that it was above 0.05 so it could be concluded that there was no difference in online check-in online service on both companies.

\section{REFERENCES}

1. Aggarwal, C. C. (2015). Outlier analysis. In Data mining (pp. 237-263). Springer, Cham.

2. Field, A. (2009). Discovering Statistics Using SPSS. Los Angeles, London, New Delhi, Washington DC: Sage Publications Ltd. 
3. Graham, R. J., Garrow, L. A., \& Leonard, J. D. (2010). Business Travelers' Ticketing, Refund, and Exchange Behavior. Journal of Air Transport Management, 196-201.

4. Huberty, C. J., \& Olejnik, S. (2006). Applied MANOVA and discriminant analysis (Vol. 498). John Wiley \& Sons.

5. Mendenhall, W., Beaver, R. J., \& Beaver, B. M. (2012). Introduction to probability and statistics. Cengage Learning.

6. Murali, S., Pugazhendhi, S., \& Muralidharan, C. (2016). Modelling and Investigating The Realtionship of After Sales Service Quality With Costumer Satisfaction, Retention and Loyalty - A Case Study of Home Appliances Business. Journal of Retailing and Consumer Services, 67-83.

7. Pleanggra, F., \& Yusuf, E. A. (2012). Analisis Pengaruh Jumlah Obyek Wisata, Jumlah Wisatawan dan Pendapatan Perkapita Terhadap Pendapatan Retribusi Obyek Pariwisata 35 Kabupaten/Kota di Jawa Tengah (Doctoral dissertation, Fakultas Ekonomika dan Bisnis).

8. Saleh, M. T. (2013). AFTA 2014 : Bsinis Tur dan Travel Mulai Khawatir. Retrieved from http://industri.bisnis.com

9. Santoso, S. (2017). Statistik Multivariat Dengan SPSS. Jakarta: PT Elex Media Komputindo.

10. Sugiyono. (2014). Metode Penelitian Manajemen. Bandung: Alfabeta.

11. Tabachnick, B. G., \& Fidell, L. S. (2001). Using Multivariate Statistics 4th Edition. Boston: Allyn \& Bacon. 